\author{
Czucziné Keresztes Anita
}

\title{
TAGÁLLAMI INTEGRÁCIÓS MODELLEK KÖNYVISMERTETÉS
}

\author{
Member State Integration Models
}

Czucziné Keresztes Anita jegyző; doktori hallgató, Nemzeti Közszolgálati Egyetem Közigazgatás-tudományi Doktori Iskola, keresztesanita@gmail.com

Valamennyi tagállamra azonos szabályok vonatkoztak az európai integráció Maastricht elötti unitárius szerkezetében. Többsebességü integráció lehetséges a Gazdasági és Monetáris Unió rendszerében: különféle kormányzási modellek, bonyolult intézményi feltételek állnak fenn.

Milyen változásokat hozhatna az „európai gazdasági kormányzás”, illetve a „teljes” gazdasági unió kiépitése az EU intézményi szerkezetében? Hogyan alakulna e körülmények között az euróövezetbe tartozó, illetve az abból kimaradó tagállamok helyzete? Milyen eltérések lehetnek az egyes tagállamok között az uniós szabályok alkalmazásában? Milyen szerepet tölthet be a megerősített együttmüködés a tagállamok szükebb csoportjának mélyebb integrációjában? Hogyan alakulhat a mediterrán periféria, illetve a közép- és kelet-európai „új tagállamok” pozíciója? Többek között a fenti kérdésekre is választ kapunk a kötetben.

KulCsSzavaK:

differenciált, integráció, kohézió, reform, unió

All member states were subject to the same rules in the pre-Maastricht unitary structure of European integration. Multi-speed integration is possible in the Economic and Monetary Union system: different governance models, complex institutional conditions.

What changes could the construction of a "European economic governance" or a "full" economic union bring to the institutional structure of the EU? How would the situation of Member States in and out of the euro area evolve under these circumstances? What differences might there be between Member States in the application of EU rules? What role could enhanced cooperation play in the deeper integration of a narrower group of Member States? How might the position of the Mediterranean periphery and the "new Member States" of Central and Eastern Europe evolve? Among other things, these questions are answered in this volume.

KEYWORDS:

cohesion, differentiated, integration, reform, union 
A Tagállami integrációs modellek címü kötet 2019-ben jelent meg a Dialógus Campus Kiadó gondozásában. A mü A modern állam gazdasági szerepének legújabb dimenziói elnevezésű Ludovika Kiemelt Kutatóműhely kutatásai keretében készült el. A kötet szerkesztője és egyik szerzője Halmai Péter, a kutatóműhely vezetője. A könyv A gazdasági kormányzás új dimenziói az Európai Unióban alcímet viseli. A kötet 13 fejezetre tagolódik. A fejezeteket 11 szerző írta.

Az Elöszó ${ }^{1}$ exponálja a differenciált integráció témakörét, majd jelzi fejlődésének mérföldköveit. Ugyanakkor jelzi: a dezintegrációt a brexit példáján a kutatás keretében külön kötetben dolgozza fel.

A Bevezetés: tagállami integrációs modellek címü indító egység² (szerzője Halmai Péter) bemutatja: a differenciált integráció gyökerei az európai integráció kezdetéig nyúlnak vissza, azonban a koncepció valódi térnyerése csak az 1980-as években indult, amikor megjelent az Európai Közösségek elsődleges joganyagában is. Később valamennyi alapés módosító szerződés szövege hivatkozik a differenciált együttműködésre, egyre inkább konkretizálva az uniós szerződésen alapuló differenciált együttműködés feltételrendszerét.

A differenciált integráció folyamat, amelyben a tagállamok specifikus csoportja nincs alárendelve a többiekkel azonos uniós szabályoknak. A megkülönböztetés hosszú, közép-, illetve rövid távú is lehet. Hatást gyakorol az Európai Unió joganyagának elsődleges vagy másodlagos szintjére, de akár a kívülálló államokat is érintheti. Alapvető kérdés: a differenciált integráció az európai integráció szükségszerủ strukturális attribútumaként jött-e létre, illetőleg e folyamat a mag-Európa megerősödéséhez vagy az EU atomizálásához vezet-e. ${ }^{3} \mathrm{~A}$ továbbiakban bemutatja sorrendben a 12 fejezet tartalmát.

Palánkai Tibor Integráció és kohézió az EU-ban címü tanulmányát ${ }^{4}$ két részre osztja. Az első részben az integráció fogalmának magyarázatával indítja művét. Véleménye szerint az integráció közösségek képződésének, fejlődésének, újratermelődésének és átalakulásának történelmi folyamata. A társadalmi formációk vagy szerkezetek elemzésével próbál választ adni arra, hogy mit tekinthetünk integrált közösségnek. Az integráció maga is strukturált folyamat: többszintü, többfunkciós és többdimenziós. Az integrációs folyamatok általában sokszereplősek, ahol az elsődleges szereplő az egyén. A nemzetközi integráció mint az államközi regionális és a globális integrációs folyamat új fejlemény. A II. világháborút követő évtizedek terméke. Habár az EU mellett több tucat más integrációs célú szervezet müködik, mégis az EU kiemelkedő mind közül magas szintü

Halmai Péter (szerk.): Tagállami integrációs modellek. A gazdasági kormányzás új dimenziói az Európai Unióban. Budapest, Dialóg Campus, 2019c. 11-14.

Halmai (szerk.) (2019c): i. m. 15-26.

A kötetben terjedelmi okokból külön nem szerepel a Brexit különösen bonyolult témaköre. Ugyanakkor a mü alapját képező, fentebb jelzett kutatás keretében behatóan vizsgálták a Brexit problémakörét. Lásd Halmai Péter: A Brexit lehetséges gazdasági hatásai. Európai Tükör, 21. (2018a), 2. 7-32; Halmai Péter: A dezintegráció gazdaságtana. A brexit esete. Közgazdasági Szemle, 67. (2020a), 9. 837-877; Halmai Péter (szerk.): A brexit forgatókönyvei és hatásai. Budapest, Dialóg Campus, 2020; Halmai Péter: A populizmus ára: a Brexit adó. Magyar Tudomány, 181. (2020), 12. 1621-1635.

4 Halmai (szerk.) (2019): i. m. 27-50. 
integritásával. Kiemeli, hogy a nemzetek változatlanul a jelenlegi integrációs folyamatok és szerkezetek fontos összetevői, amelyben a nyitott, együttmüködő, befogadó és versenyző nemzetek alkalmazkodással integrálódnak. Az alfejezet végén felmerül a „globális nemzet" fogalmának bevezetése is.

A fejezet második része a Kohézió - válság - reformok címet viseli. Véleménye szerint a kohézió minden integrációs közösség alapvető attribútuma. Az integrált közösségekben a kohézió feltételezi, hogy az integrációs előnyök mindenki számára érzékelhetők és elérhetők. Habár a globális integráció jelentős jóléti előnyöket hozott mindenki számára, azt nem mindenki érzékeli. Megállapítja, hogy a globális integráció szembeötlő kísérőjelensége, mondhatni torzulása, hogy nemcsak az egyenlötlenségek növekedésével jár együtt, hanem ezek az elmúlt évtizedekben szélsőséges méretet öltöttek. A kialakuló egyenlőtlenségekre az EU sem volt képes egyértelmű és hatékony választ adni, ami kohéziós válsághoz vezetett: az integráció támogatottsága visszaesett, az európai értékekkel történő azonosulás meggyengült, és a negatív azonosulás erősödött. Véleménye szerint fontos lenne tisztázni, mi legyen a „szociális állam” célja, és azt milyen szociális modell szolgálná leginkább. Álláspontja szerint az új társadalom- és gazdaságszervezési modell a megreformált és megjavított jóléti állam és szociális piacgazdaság elveire egyaránt építhetne. A megoldást szerinte a demokratikus és versenyképes ökoszociális piacgazdaság hozná.

A következő fejezet Koller Boglárkától a Többsebességes vagy menüválasztásos jövő? A differenciált integráció elméleti és gyakorlati kérdései az Európai Unióban címet viseli. ${ }^{5}$ A szerző tanulmánya elején Jean-Claude Juncker Az Unió helyzete 2017 című beszédjének mondandóját taglalja, miszerint a differenciált integráció, habár visszatérő eleme az Unió jövőjének, az Unió egységes, és a tagok egyenlők. A differenciált integráció csak az 1990-es években vált az európai integráció fejlődését meghatározó iránnyá és meghatározza az európai integráció jövőbeni útját. Ennek alátámasztására röviden bemutatja a koncepció evolúcióját, különös tekintettel a különböző politikai, jogi és tudományos értelmezésekre. A bemutatás során kitér a Lisszaboni Szerződésre, amely mérföldkőnek tekinthető a differenciált integráció szerződéses alapú megvalósulásában. Ezután a differenciált integráció fogalmát taglalja. A tanulmány amellett érvel, hogy a differenciált integrációra mint az európai egységfolyamatot magyarázó új teóriára érdemes tekinteni. A differenciált integráció ugyanis újraértelmezi az integrációelméletek eddig használt teóriáit, így a neofunkcionalista, a kormányközi és az úgynevezett hibrid elméleteket az integráció folyamata és a végcélja megítélésének tekintetében is. A szerző a tanulmány legvégén a differenciált integráció lehetséges „integráló” és „dezintegráló” hatásairól is szót ejt.

Halmai Péter Differenciált integráció: gazdasági integrációs modellek című tanulmányát a differenciált integráció fogalmának analitikus magyarázatával indítja, ${ }^{6}$ majd a differen-

Halmai (szerk.) (2019c): i. m. 51-66.

6 Halmai (szerk.) (2019c): i. m. 67-142. Az átfogó koncepcionális keretekről lásd Halmai Péter: Európai integráció és szuverenitás: A gazdasági kormányzás új dimenziói. Magyar Tudomány, 174. (2013), 4. 411-421; Halmai Péter: Európai gazdasági integráció. Budapest, Ludovika Egyetemi Kiadó, 2020; Halmai Péter: Mélyintegráció. A Gazdasági és Monetáris Unió ökonómiája, Budapest, Akadémiai Kiadó, 2020. 
ciált integráció koncepcióinak és kategorizálásának bemutatására kerül sor: a „többsebességes Európa”, a „mag-Európa”, a „változó geometriák” és az „à la carte Európa” változatai áttekintésére. Véleménye szerint a differenciálás realitásának megítéléséhez elsősorban két fontos sajátosságot kell figyelembe venni: egyrészt az időtényezőt, másrészt az Európai Unió joganyagában történő elhelyezkedésüket. Az időtényező döntő jelentőségü módon befolyásolhatja a differenciálás formáját, amely rövid távú, átmeneti elrendezés, középtávra szóló vagy hosszú távú lehet. Az EU-jog keretén kívüli differenciálás esetén a tagállamok meghatározott csoportjának együttmüködése kerül a nemzetközi jog hatálya alá. Az Európai Unió a differenciált integráció rendszere, amely a centralizációs szintek változatai (vertikális differenciálódás) és a territoriális kiterjedés (horizontális differenciálódás) változatai tekintetében egyaránt érvényes a különféle szakpolitikai területeken.

A differenciált integráció modellje a kölcsönös függőség és a politizáció (átpolitizáltság) kölcsönhatásában értelmezhető. Belső differenciálódást, szupranacionális integrációt és külső differenciálódást (kívülálló államok szelektív politikai integrációját) különböztet meg. Összegezve: a vertikális differenciálás az európai integrációban mindig meghaladta a horizontális differenciálást. Ugyanakkor a vertikális differenciálás viszonylag stabil maradt, a horizontális differenciálás pedig növekedett az elmúlt 30 év során. Megállapítja azt is, hogy a differenciálás tartós és növekvő jelentőségű jellemzője az európai integrációs modellnek. Majd a krízisek jelentőségét hangsúlyozza, amely további reformokat válthat ki, ami még több integrációhoz vezet. Megállapítja: az európai integráció fejlődését a mélyülés, a bővülés és a differenciálás jellemzi. A kölcsönös függőség és az átpolitizáltság a differenciált integráció fő hajtóerői. Leírja, hogy mikor, mi jellemző az átpolitizáltságra. Amikor már erősen megjelenik az euroszkepticizmus, akkor a folyamat külső differenciálást eredményez. A differenciálás alapja az exogén és endogén kölcsönös függés további növekedése. A tartósan érvényesülő kölcsönös függőség nyomása és az integráció átpolitizáltsága mélyíthetik a különbséget az euróövezet és az Európai Unió többi része között.

A szerző álláspontja szerint a tagállamok megegyezésén alapuló, differenciált integráció pragmatikus, második legjobb megoldás. Annak minden EU-tag elött nyitva kell állnia. A differenciálás módszere egyes szakpolitikák terén alkalmazható, átmeneti konstrukció a hatékonyabb és egységes döntéshozatal felé vezető úton. A differenciált integráció nem léphet az egyre szorosabb Unió (a mélyintegráció rendszere) kiépítése folyamatának helyébe. Nem vezethet első- és másodrangú EU-tagság kialakulásához. Végső célja a befogadás elömozdítása, nem pedig a tagállamok kizárása. További, elkerülendő veszélyek a politikai és intézményi fragmentáció, illetve a döntéshozatali folyamat még bonyolultabbá válása.

A magországok és a periféria között a legutóbbi két évtizedben jellemzővé vált a strukturális divergencia. Egyes tagállamok a versenyképesség helyreállításához, illetve emeléséhez szükséges strukturális reformokat nem valósították meg. Az egyes tagállamok között fennálló strukturális eltérések magyarázzák meg, miért alakultak ki tartós egyensúlytalanságok az euróövezetben, illetve mely tényezők és ágazatok meghatározók a gazdasági 
növekedésben.7 A tanulmány azzal a megállapítással zárul, hogy a teljes gazdasági unió, az európai gazdasági kormányzás kiépülése valódi esélyt kínál az európai gazdaság problémáinak megoldására, az európai magövezetből történő kimaradás pedig szükségképpen a perifériára szorulás veszélyét hordozza.

Benczes István Maastrichti kompromisszum: vele vagy nélküle? címü tanulmánya ${ }^{8}$ a fiskális szabályok szigorítására, valamint a fiskális unió lehetőségeire koncentrál. Az Európai Unió a fiskális szabályok szigorításával, majd tagállami szintű kötelező érvényesítésével konkrét lépéseket tett. Azonban az intézményi reformokat megjeleníteni hivatott fiskális unió jobbára még mindig csak ötlet maradt. Benczes István tanulmánya ugyan nem vitatja a mostani lendület fontosságát, ám kritikusan szemléli a fiskális unió megteremtésének folyamatát. A fiskális unió - ha lesz is - nem valószínű, hogy nagyobb lenne, mint a tagok GDP-jének 1,5-2\%-a. Mint ilyen, nem lehet majd több alkalmi stabilizációs eszköznél, amelyet csak kivételes esetekben aktiválnak a felek. Ez pedig nyilván nagyon messze van attól, hogy a tagállamok annak révén későbbi politikai unió alapjait fektessék le. Ami tíz esztendővel a pénzügyi és gazdasági válság kirobbanása és 30 évvel a Delors-jelentés publikálása után továbbra is egyértelmü: a maastrichti kompromisszum meghaladása ugyan távlati cél lehet, de ennek teljesülése rövid távon nem túlzottan valószínü.

Csaba László A költségvetési és bankunió: vízválasztó a többsebességes EU-ban címü munkájában ${ }^{9}$ arra a kérdésre keresi a választ, hogy a Költségvetési és Bankunió (KBU) eddigi müködési tapasztalatai és a várható kiegészítő intézkedések mennyiben jelentenek új szakaszt az európai integráció fejlődésében. Megállapítja: az Európai Unió alapjaiban alakult át a 2008-2012. évi időszak válságkezelő intézkedései hatására. Jelentősen megnőtt a nemzetek fölötti, technokratikus döntések súlya a kormányköziek ellenében. Az euróövezetben új minőségű, szupranacionálissá mélyült integráció jött létre. A bankfelügyelet nemzetek fölötti szintre kerülése, a részvényesek kötelező bevonása meggyengítette a kontinentális banki modell egyik alapvonását. Leírja, hogy a bankunión belül sokkal inkább piacelvü és technokratikus gyakorlat alakul ki. Szerinte meghaladottnak tűnik az az érvelés, amely kifejezetten óv attól, hogy az EMU (European Monetary Union) és föleg a KBU elkülönült és tartós intézményi struktúrává váljon. Csaba László a tanulmányt azzal a megállapítással

Előbbiek a szerző fontos integrációgazdaság-tani művein alapulnak. A legutóbbi évekből kiemelést igényelnek: Halmai Péter: Krízis és növekedés az Európai Unióban. Európai modell, strukturális reformok. Budapest, Akadémiai Kiadó, 2014; Halmai Péter: Az európai növekedési potenciál eróziója és válsága. Közgazdasági Szemle, 62. (2015), 4. 379-414; Halmai Péter: Új geometria: „teljes” gazdasági és monetáris unió? A gazdasági kormányzás új dimenziói az Európai Unióban. Magyar Tudomány, 178. (2017), 1. 6-17; Halmai Péter: Az európai növekedési modell kifulladása. Közgazdasági Szemle, 65. (2018b), 2. 122-160; Halmai Péter: Európai reformok: Többsebességü Európa? Differenciált gazdasági integráció versus átfogó reform. Európai Tükör, 21. (2018c), 3. 21-44; Halmai Péter: Konvergencia és felzárkózás az euróövezetben. Közgazdasági Szemle, 66. (2019b), 6. 687-712; Halmai Péter: Felzárkózás és konvergencia az európai integráció rendszerében. In Közel Európa távol. Budapest, Éghajlat, 2019a. 189-230; Halmai Péter: GMU 2.0? Felelősség versus szolidaritás? Külgazdaság, (2020b), 9-10; Halmai Péter: Középpontban a reziliencia. A Gazdasági és Monetáris Unió mélyülésének egyes tényezői. Pénzügyi Szemle, (2021), 1. 7-31.

8 Halmai (szerk.) (2019c): i. m. 143-166.

9 Halmai (szerk.) (2019c): i. m. 167-182. 
zárja, hogy a részletek folytonos változtatása mindig elégséges egérutat jelent a döntéshozóknak.

A következő fejezet Kutasi Gábortól a Külső egyensúlytalanság az euróövezetben. Megoldás-e a többszintü kormányzás? címet viseli. ${ }^{10}$ A tanulmány azzal a gondolatmenettel indul, hogy az euróövezet adósságválsága az egységes piac strukturális problémáját hozta felszínre: annak alapja az eladósodott tagállamok külső egyensúlyi problémája. Mivel az euróövezetbe tartozó tagállamok közösségét egységes piacnak tekintették, az egyes tagok közösségen belüli folyó fizetési mérlege mellékes kérdésnek tünt. Az egységes valuta, az euró a tagállamok között rögzített árfolyamrendszert eredményezett. Így a kevésbé versenyképes országok nem tudják javítani a béralapú versenyképességüket árfolyam-leértékelésen keresztül, miközben az egységes központi banki kamatszint és az euróövezet stabilitása által biztosított olcsó finanszírozási lehetőségek arra ösztönözték őket, hogy a jelenbeli fogyasztásukat bővítsék. A tanulmány a folyó fizetési mérleg reáleffektív árfolyammal fennálló összefüggésére koncentrál. Ugyanakkor, ahogy a műben látjuk, azon túl még számos más tényező befolyásolja a folyó fizetési mérleg alakulását. A szerző a tanulmányt azzal a gondolatmenettel zárja, hogy mi történne akkor, ha az EU euróövezeti kötvényeket bocsát ki. Megállapítja, hogy nem várható rövid távon az integráció ez irányú mélyülése. Arra is érdemes emlékeztetni, hogy az egységes piac és az egységes valuta lehetetlenné teszi a közvetlen beavatkozást a magánszektor külföldi eladósodásának és az importigény alakulásának folyamatába. A pénzügyi konvergencia vegyes képet mutat a tagállami pénzügyi piacok méretére, koncentráltságára, vállalat-összetételére, finanszírozási struktúrájára vonatkozóan.

Győrffy Dóra Erkölcsi kockázat és szolidaritás a GMU-ban: a görög válság tanulságai címủ tanulmányát ${ }^{11}$ azzal az izgalmas gondolatmenettel kezdi, hogy a globális pénzügyi válság számos korábbi tabut semmivé tett a GMU tekintetében, amelyek közül az egyik legfontosabb az úgynevezett nincs kimentés szabály. Az EKB beavatkozásai, illetve az egyes országoknak nyújtott nemzetközi mentőcsomagok immár erősen megkérdőjelezték annak relevanciáját, ám a szabály mögötti megfontolások nem tűntek el. Az erkölcsi kockázattól való félelem, azaz, hogy a kimentések a befektetőket felelőtlen hitelezésre ösztönzik, folyamatosan jelen volt a mentőcsomagok tárgyalása során. E félelem ütközött a szolidaritás elvével: ha valamely tagállam bajba kerül, megsegítése az Unió egészének érdeke és felelössége.

A tanulmány bemutatja a görög euróövezeti tagság fenntartásával kapcsolatos legfontosabb megfontolásokat. A görög gazdaság szerkezetének és az adósság összetételének áttekintése alapján rávilágít arra: az ország kilépése az euróövezetből nem oldana meg semmilyen problémát a görög gazdasággal kapcsolatosan, ám hatalmas költségei lennének mind a görög lakosság, mind pedig az euróövezet többi tagállama számára. Mindez magyarázhatja azokat a rendkívüli áldozatokat, amelyeket Görögország és európai partnerei

Halmai (szerk.) (2019c): i. m. 183-196.

Halmai (szerk.) (2019c): i. m. 197-208. 
vállaltak az euróövezet egybentartásáért. A tanulmány gondolatait azzal a megállapítással zárja, hogy az intézményi és szerkezeti reformokat elősegíti a szupranacionális szint rendkívüli megerősödése az európai és különösen a görög pénzügyi válság kezelése során. A kimaradók nagyobb gazdaságpolitikai szabadságot élveznek, de ez egyben azt is jelenti, hogy egyre inkább másodlagos szereplőkké válnak az Európai Unió döntéshozatali rendszerében - várhatóan nem csupán az euróövezettel összefüggő kérdésekben. Ugyanakkor az erkölcsi kockázat és szolidaritás dilemmája esetükben továbbra is megoldatlan.

A görög válság után a jogharmonizáció kerül középpontba, Kecskés László $A$ jogharmonizáció integráló erejének gyengülése című tanulmányában. ${ }^{12}$ A szerző az Európai Közösségek jogi müködésének 1958. évi kezdetétől a jogharmonizációs tevékenységnek integrációt erősítő szerepét mutatja be: a rendeletek jogharmonizációs eszközként való „újrafelfedezésével” egyrészt a jogharmonizáció a korábbinál is hatékonyabb integrációerősítő funkciót kapott. Ugyanakkor az Egységes Európai Okmány mintegy „be is cikkelyezte” a tagállamok közösségi központtal szembeni jogharmonizációs mozgásterének jogalapjait.

Kiemeli, hogy a Maastrichti Szerződés révén „újra felfedezett” szubszidiaritás elvileg a jogharmonizáció tagállami érdekdimenzióit, továbbá az alaposabb jogászi-szakmai előkészítő munkát erősítette.

A továbbiakban a Frankovich-ítélet, az úgynevezett Frankovich-jelenség, illetve a Frankovich-elv kerülnek a gondolatmenet középpontjába. Alapvető jelentőségű a jogharmonizációban engedetlen vagy hanyag tagállamokkal szemben az állami kárfelelösség intézményeinek alkalmazhatósága. Az 1990-es évek közepére az Európai Bíróság elbizonytalanodott: az úgynevezett post-Frankovich-jelenség keretében jogi fékezési mechanizmusokat alakított ki a Frankovich-elv progresszivitásával szemben.

Király Miklós A nemzetközi magánjog kodifikálásának útjai az Európai Unióban és tagállamaiban címü tanulmánya ${ }^{13}$ a jogegységesítésről a nemzetközi magánjog területén szól. A tagállami integrációs modelleket vizsgáló kutatások között első pillantásra viszonylag szüknek tűnő terület nagyon sokrétü szabályozást foglal magában, számos kérdéssel és problémával. A fő kérdés, amely a kötet központi témájához is kapcsolódik: milyen hatást gyakorol a tagállami jogalkotásra valamely nagy uniós jogi normatömeg?

Összességében - mint annyi más területen -, itt is szerves együttélés alakul ki az EU-jog és a tagállami jogok között. A jogharmonizáció nem teljes, az átfogó szabályozást a két normarend együttesen adhatja. Bár lelassulni látszik a további jogegységesítés, így is érintkező világokról van szó. Az új nemzeti kódexek nem vonhatják ki magukat az EU-jog hatása alól.

Várkonyi László Intézményközi harcok az EU kereskedelempolitikai döntéshozatali, jogalkotási folyamataiban címü tanulmányában ${ }^{14}$ bemutatja: a közös kereskedelempolitika az Európai Gazdasági Közösség létrejötte és a Lisszaboni Szerződés életbelépése közötti évtizedekben lényegében két szereplő, az Európai Bizottság és a tagállamok képviselőiből

\footnotetext{
Halmai (szerk.) (2019c): i. m. 209-228.

Halmai (szerk.) (2019c): i. m. 229-236.

Halmai (szerk.) (2019c): i. m. 237-248.
} 
álló Tanács közötti küzdelmekben formálódott. Az Európai Bizottság és a tagállamok között folyamatos viták folytak arról, hogy mi is a közös kereskedelempolitika pontos tartalma, hol hozhatnak a tagállamok nemzeti szabályokat, vagy folytathatnak nemzetközi tárgyalásokat, mennyiben lehetnek közvetlenül is aktív résztvevői multilaterális vagy kétoldalú tárgyalásoknak, illetve részes felei a nemzetközi szerződéseknek.

Kiemeli, hogy az Amszterdami Szerződés és a Nizzai Szerződés is részlegesen tágította a szolgáltatások kereskedelmére és a szellemi tulajdonjogok kereskedelmi vonzataira vonatkozó közösségi hatáskör tartalmát. A Lisszaboni Szerződés viszont e területekre, sőt a külföldi közvetlen befektetésekre is teljeskörűen kiterjesztette a közös kereskedelempolitika hatókörét. Mindezek alapján lehetővé válik olyan szabadkereskedelmi megállapodások létrehozása, ahol az eddig követett gyakorlattal ellentétben már kizárólag az EU jelenik meg részes félként, a tagállamok pedig nem. A Lisszaboni Szerződés különösen jelentős változást hozott azzal, hogy megszüntette a Tanács addigi egyedüli jogalkotó szerepét a közös kereskedelempolitikában. Az Európai Parlament (EP) az uniós szabályozásoknál társjogalkotóvá vált, a nemzetközi kereskedelmi szerződések megkötéséhez pedig immár az EP egyetértése is szükségessé vált. Ezzel az EU közös kereskedelempolitikájának alakításában a Bizottság és a Tanács mellett az EP is érdemi szereplő lett ennek minden elönyével és nehézségével.

Az intézmények közötti új egyensúly megtalálását és a zavartalanabb együttmüködést az EP szerepének megerősödése önmagában nem oldja meg. Sőt a kereskedelempolitika kizárólagos uniós hatásköreinek kibővülése miatt a nemzeti parlamentek elveszíthetik korábbi jogosítványaikat a kereskedelmi megállapodások jó részének ratifikálására, ami várhatóan újabb problémákat és feszültségeket teremt.

A kötet következő tanulmánya (szerzője Hetényi Géza) a Többsebességes Európa - magyar érdekek a GMU mélyitése során címet viseli. ${ }^{15}$ A szerző írásában aláhúzza, hogy a többsebességes európai integráció legkézzelfoghatóbb megjelenése a GMU, majd kiemeli a GMU szerepét, és azt, hogy habár a tagországok közül hétnek (például Magyarországnak) az alapító szerződések rendelkezései alapján törekednie kell az euró bevezetésére, illetve az ehhez szükséges feltételek megteremtésére, ez nem kikényszeríthető. Svédország példáján keresztül mutatja be, ha nincs rá belső politikai akarat, akkor egy-egy tagállam a feltételek teljesülése esetén sem feltétlenül csatlakozik az euróövezethez. Kizárólag Dánia és az Egyesült Királyság rendelkezett kimaradási joggal, amely az utóbbi esetében a brexittel természetesen okafogyottá vált. Hangsúlyozza: míg az euróövezetben részt nem vevő tagállamok is léteznek, egyértelmüen kétfokozatú integrációról beszélhetünk. A közös monetáris politika és a közös fizetőeszköz, kiegészülve azokkal a fiskális szabályokkal, amelyek csak az euróövezet országaira vonatkoznak, egyértelmüen magasabb fokú integrációt jelentenek.

15 Halmai (szerk.) (2019c): i. m. 249-262. 
Várkonyi László a kötetben szereplő másik tanulmányában (Lisszaboni Szerződés: EU-s és tagállami beruházási hatáskörök $)^{16}$ ugyancsak a közös kereskedelempolitika témakörét tárgyalja. A Lisszaboni Szerződés több, látszatra apróbb, de jelentős hatású módosítást hozott az EU közös kereskedelempolitikájában. Kibővült annak tárgyi hatálya, és külföldi közvetlen beruházások is a részévé váltak. Mindez hosszú belső vitákat váltott ki az Európai Bizottság és a tagállamok között, súlyos (teljesen máig sem egyértelmüen megoldott) kérdéseket vetve fel.

Összegzésképpen megállapítható: a több intézményt átfogó, kiváló kutatókból álló szerzői gárda a kötet elkészítésével lényeges mértékben járult hozzá a témakör jobb rendszerezéséhez és az összefüggések áttekintéséhez. Külön kiemelést igényel a dezintegráció problémaköre, amelyet e kötetben inkább csak jelzésként említenek. A dezintegráció, azon belül a differenciált dezintegráció esetleges lehetőségeinek (veszélyeinek) további vizsgálata akkor is lényeges feladat, ha a fő irányzat a jövőben is az európai integráció mélyülése.

16 Halmai (szerk.) (2019c): i. m. 263-278. 


\section{FELHASZNÁLT IRODALOM}

1. Halmai Péter: Krizis és növekedés az Európai Unióban. Európai modell, strukturális reformok. Budapest, Akadémiai Kiadó, 2014.

2. Halmai Péter: Az európai növekedési potenciál eróziója és válsága. Közgazdasági Szemle, 62. (2015), 4. 379-414. Online: http://epa.oszk.hu/00000/00017/00225/pdf/ EPA00017_kozgazdasagi_szemle_2015_04_379-414.pdf

3. Halmai Péter: Új geometria: „teljes” gazdasági és monetáris unió? A gazdasági kormányzás új dimenziói az Európai Unióban. Magyar Tudomány, 178. (2017), 1. 6-17. Online: http://epa.oszk.hu/00600/00691/00160/pdf/EPA00691_mtud_2017_01_006-017.pdf

4. Halmai Péter: A Brexit lehetséges gazdasági hatásai. Európai Tükör, 21. (2018a), 2. 7-32. Online: https://doi.org/10.32559/et.2018.2.2

5. Halmai Péter: Az európai növekedési modell kifulladása. Közgazdasági Szemle, 65. (2018b), 2. 122-160. Online: https://doi.org/10.18414/KSZ.2018.2.122

6. Halmai Péter: Európai reformok: Többsebességü Európa? Differenciált gazdasági integráció versus átfogó reform. Európai Tükör, 21. (2018c), 3. 21-44. Online: https:// doi.org/10.32559/et.2018.3.3

7. Halmai Péter: Felzárkózás és konvergencia az európai integráció rendszerében. In Közel Európa távol. Budapest, Éghajlat, 2019a 189-230.

8. Halmai Péter: Konvergencia és felzárkózás az euróövezetben. Közgazdasági Szemle, 66. (2019b), 6. 687-712. Online: https://doi.org/10.18414/KSZ.2019.6.687

9. Halmai Péter (szerk.): A brexit forgatókönyvei és hatásai. Budapest, Dialóg Campus, 2020.

10. Halmai Péter: Tagállami integrációs modellek. A gazdasági kormányzás új dimenziói az Európai Unióban. Budapest, Dialóg Campus, 2019c. Online: https://antk.uni-nke. hu/document/akk-copy-uni-nke-hu/web_PDF_Tagallami_integracios_modellek.pdf

11. Halmai Péter: A dezintegráció gazdaságtana. A brexit esete. Közgazdasági Szemle, 67. (2020a), 9. 837-877. Online: http://doi.org/10.18414/KSZ.2020.9.837

12. Halmai Péter: GMU 2.0? Felelősség versus szolidaritás? Külgazdaság, 64. (2020b), 9-10. 3-34. Online: https://doi.org/10.47630/KULG.2020.64.9-10.3

13. Halmai Péter: Középpontban a reziliencia. A Gazdasági és Monetáris Unió mélyülésének egyes tényezői. Pénzügyi Szemle, (2021), 1.7-31. Online: https://doi.org/10.35551/ PSZ_2021_1_1

Czucziné Keresztes Anita tíz éve jegyzőként dolgozik, de közel ötéves nemzetközi közigazgatási tapasztalattal is rendelkezik. Igazgatásszervező végzettségét 2005-ben szerezte a Budapesti Corvinus Egyetem Államigazgatási Főiskolai Karán. Németországban 2008-ban végzett a Fachhochschule Ludwigsburg/Kehl Europäisches Verwaltungs-management mesterszakon, ahonnan európai uniós közigazgatási menedzsment diplomával tért haza. A Nemzeti Közszolgálati Egyetem Közigazgatás-tudományi Doktori Iskolájában folytatott doktori tanulmányai során azt vizsgálja, hogy miként történik a közigazgatás személyi állományának képzése hazánkban, illetve a világ más országaiban. 